\title{
O GÊNERO DIÁRIO NA FORMAÇÃO INICIAL DO PROFESSOR
}

Cláudia Valéria Doná Hila ${ }^{1}$

Resumo: Vinculado ao grupo de pesquisa "Interação e escrita no ensino e aprendizagem" (UEM/CNPq), o objetivo deste trabalho é discutir resultados parciais sobre o papel do gênero diário como instrumento de interlocução entre professor formador e professor em formação durante a disciplina de Prática de Ensino de Língua Portuguesa. O referencial teórico ancora-se no interacionismo social e no interacionismo sócio-discursivo bronckartiano. Os professores em formação produziram, ao longo do ano letivo de 2006, diários introspectivos nos quais o objetivo maior era obter uma interação mais efetiva entre professor formador e professor em formação, tendo em vista, principalmente, o baixo índice de motivação e de confiança em si mesmos com que os acadêmicos chegam a essa disciplina. Entretanto, para além dessa função, outros papéis desse gênero foram aparecendo. Esse estudo aponta para a importância de vermos os gêneros textuais como uma ferramenta psicológica (cf. SCHNEUWLY, 1994), no sentido vygotskyano do termo, o que quer dizer que o diário pode ser considerado um instrumento catalisador na formação inicial.

Palavras-chave: diário; interação; escrita. 


\section{Introdução}

A formação reflexiva do professor tem sido considerada essencial no decorrer da formação docente (LIBERALI, 1997, 1999; MAGALHÃES, 1998; GIMENES, 2002). No caso específico da formação inicial, o professor em formação (doravante professorando) do curso de Letras, da Habilitação Única/Português (noturno), da Universidade Estadual de Maringá(UEM), vivencia o seu momento de estágio de docência praticamente ao final do curso. Nesse contexto, tem sido muito comum os acadêmicos chegarem a esse momento de sua formação com alguns impedimentos relevantes para o desenvolvimento do estágio de docência, tais como: desmotivação com o curso; marcação do não desejo de serem professores; baixa-estima e passividade na posição de "alunos"; medo (em alguns casos pavor) no enfrentamento do estágio de docência; dificuldade em correlacionar conteúdos vistos durante e curso; não vivência da transposição didática de conteúdos a serem ensinados na educação básica (Hila, 2006).

Frente a esse cenário os professores formadores da disciplina acabam, também, vivenciando outras tensões: a impossibilidade de darem conta de suprir todas as carências teórico/metodológicas apresentadas pelos professorandos; a dificuldade de também fornecerem subsídios emocionais para esses professorandos para o momento da regência; a dificuldade de desenvolverem em pouco mais de dois meses um projeto de docência, tendo em vista os problemas anteriormente apresentados pelos acadêmicos.

Nesse confronto, temos realizado, ao longo dos últimos anos, em parceria com outros professores orientadores, algumas tentativas para minimizar essas questões, em especial pensando: 1) nas lacunas teóricas; 2) nas metodológicas; 3 ) nas emocionais e reflexivas.

Já aprendemos, ao longo de nossa prática, como orientadoras, pelo tempo que temos de trabalho com nossos alunos, que, por exemplo, em relação às lacunas teóricas, a internalização de saberes que não foram realizados anteriormente no curso dificilmente ocorrerá no momento do estágio (ou ocorrerá muito parcialmente), exatamente porque cada indivíduo precisa de um tempo para a internalização (VYGOTSKY, 1978) que pode, em muitos casos, transcender ao momento do estágio. 
Quanto às lacunas metodológicas, ocorre situação similar. Como esses professorandos não vivenciaram (ou vivenciaram muito pouco) processos de transposição didática dos conteúdos a serem ensinados na educação básica; como jamais entraram em uma sala de aula (ou a observaram), os únicos exemplos de condutas metodológicas que trazem para o momento do estágio de docência são de seus professores em anos anteriores. Assim, tendem a repetir procedimentos que, muitas vezes, são utilizados no ensino superior ou em sua formação anterior, mas que na educação básica tornam-se impróprios ou inconsistentes.

Se não nos é possível conseguir que a maioria desses futuros professores tenha suas lacunas teóricas preenchidas, ao menos ter a pretensão de instaurar neles uma atitude reflexiva em relação a si próprios e ao seu agir pareceu-nos ser uma meta possível de ser alcançada.

Foi nesse intuito que buscamos no gênero diário uma tentativa de promover a reflexão e a interlocução mediada pela escrita com o professorando. Para tanto, temos trabalhado com vários tipos de diários: o diário íntimo/introspectivo, o diário de leitura e o diário reflexivo. Particularmente, neste artigo, enfocamos o diário íntimo que, como veremos adiante, transformou-se em um diário "compartilhado".

Assim, o objetivo desse trabalho, vinculado ao grupo de pesquisa "Interação e escrita no ensino e aprendizagem" (UEM/CNPq), é discutir resultados parciais sobre o papel do gênero diário íntimo/compartilhado durante a disciplina de Prática de Ensino de Língua Portuguesa, a partir do interacionismo social e do interacionismo sociodiscursivo bronckartiano.

Nas próximas seções, trataremos sobre o conceito de profissional reflexivo em que nos baseamos, algumas reflexões sobre o gênero diário, bem como o contexto de produção dos diários e os resultados da análise.

\section{O professorando como profissional reflexivo}

O termo reflexão assumiu, desde a década de 80, no ensino de língua materna, um papel relevante nos estudos sobre a formação do professor, e vários autores, de diferentes abordagens, têm discutido a sua utilização. 
Liberalli (1997), por exemplo, afirma que a reflexão vem, a princípio, tornar a ideologia visível, a fim de que as ações comunicativas sejam entendidas para, posteriormente, serem transformadas. Significa, ao lado disso, compreender o senso comum como sustentador das relações de poder em nossa sociedade. Refletir pressupõe, para a autora, a transformação de uma situação. Para que isso ocorra, será necessário promover um distanciamento do sujeito com o mundo do real para que ele possa ser ressignificado. Esse distanciamento implica um processo de busca interior que, gradativamente, faz com que o indivíduo tome o que é comum como estranho, e a partir daí possa desenvolver uma crescente consciência de si e do próprio mundo.

Mas será que isso quer dizer que nossos professorandos, do último ano de Letras, não refletem? Na realidade, esse processo, em grande parte das vezes, foi ocultado exatamente porque grande parte deles assume uma atitude passiva diante das aulas. Por estarem acostumados ao chamado ensino conteudístico, no qual se acredita que devam primeiro aprender o conteúdo para, posteriormente, aplicá-los na prática (e, em especial, na disciplina de Prática de Ensino), quando confrontados com práticas de sala de aula, as quais exigem a reflexão sobre os diversos saberes que nela circulam, ficam completamente desorientados. Dessa forma, o habitus $^{l}$ (ou as representações, conforme BRONCKART, 2003) adquirido em anos anteriores como alunos do curso faz com que acreditem que ensinar-aprender, por exemplo, são processos que envolvem apenas a transmissão de conhecimento e o seu recebimento formal (HILA, 2004).

A consciência que apresentam, portanto, sobre as práticas discursivas de sala de aula é quase inexistente, já que não conseguem avaliar com eficácia essas práticas, nem tão pouco suas próprias práticas. E o que lhes falta? Para nós professores supervisores, a noção de autoconsciência.

Tomando como partida os estudos vygtskyanos, poderíamos afirmar que a reflexão está associada à ideia de autoconsciência. Vygotsky (1978) esclarece-nos que são as palavras que, diferentemente dos animais, permitem ao homem dar forma à sua consciência, a qual se forma por meio da reestruturação interna das atividades sociais ou externas ao indivíduo. Assim, refletir significa ir além do 
emocional, do não consciente, mas gerar o racional e o consciente. Em outras palavras, significa transformar um processo interpessoal em intrapessoal:

Um processo interpessoal é transformado num processo intrapessoal. Todas as funções no desenvolvimento da criança aparecem duas vezes: primeiro, no nível social, e, depois, no nível individual; primeiro, entre pessoas (interpsicológica), e, depois, no interior da criança (intrapsicológica). (VYGOTSKY, 1988, p. 64).

Para o autor, portanto, o processo de internalização envolveria uma série de transformações: (1) uma operação inicialmente representada por uma atividade externa é reconstruída e passa a ocorrer internamente, a partir de operações realizadas com os signos; (2) um processo interpessoal é transformado em intrapessoal, a partir, portanto, do social para o individual, o que reitera a importância dos instrumentos de mediação; (3) "A transformação de um processo interpessoal num processo intrapessoal é o resultado de uma longa série de eventos ocorridos ao longo do desenvolvimento" (VYGOTSKY, 1988, p. 64). Esse último aspecto, aliás, chama-nos a atenção de que precisamos de tempo para amadurecer e de que o aprendizado não ocorre em uma relação temporal causal imediata.

Para que esse processo ocorra, é fundamental o papel do outro, pois é partir dele que temos a possibilidade de adquirirmos a consciência de nós mesmos. A formação dessa consciência, portanto, necessita de mediadores, não ocorrendo ao acaso. Bakthin (1992) ressalta que ao produzir um enunciado o locutor espera do outro uma resposta, uma compreensão responsiva ativa.

É no encontro entre essas duas instâncias - locutor e destinatário - que a interação se realiza e que a tomada de consciência pode emergir.Esse espaço temporal será essencial para que possamos entender o que Bakhtin (1992, p. 405-406) define como processo de monologização (que para Vygotsky é concebido como internalização): “a 'palavra do outro' se transforma, dialogicamente, para tornar-se 'palavra pessoal-alheia' com a ajuda de outras 'palavras do outro', e 
depois, palavra pessoal (com, poder-se-ia dizer, a perda das aspas)". Mesmo a fala monologizada, na perspectiva bakthininana, é dialógica, pois "na realidade, toda palavra comporta duas faces. Ela é determinada tanto pelo fato de que procede de alguém, como pelo fato de que se dirige a alguém" (p.113).

No quadro do Interacionismo Sócio-Discursivo, é pelas avaliações do outro, ainda que sejam conflitantes, que o sujeito pode se questionar, inferir, avaliar e entender o papel social que lhe cabe naquela situação de interação. Segundo Bronckart (2003), o ser humano participa, quase sempre, de diferentes formas de avaliações sociais, seja aplicando critérios de avaliação, seja julgando a própria pertinência do agir do outro.Assim, ele percebe que ao mesmo tempo avalia e é avaliado.A partir daí, desenvolvem-se representações e valorações em relação ao agir pessoal e ao agir coletivo que o constituirão como pessoa humana.

Refletir, portanto, pressupõe, quando pensamos no ensino, inevitavelmente trabalho de coautoria, de colaboração/negociação entre os participantes de uma situação determinada (professores, alunos, pais, coordenadores) e de envolvimento em discussões acerca de questões do mundo real do professorando/professor (como o que significa ensinar e aprender, as razões que justificam determinadas escolhas em sala de aula quer quanto ao conteúdo, quanto aos materiais, quanto às tarefas solicitadas, como também em relação à disciplina e organização ou, ainda, a respeito das representações dos alunos de si e dos outros) que as ações podem ser compreendidas, questionadas e repensadas (MAGALHÃES, 1998).

Além disso, a reflexão pode também ser compreendida a partir da discussão de Habermas (1989) e de sua teoria do agir comunicativo, a propósito dos interesses constitutivos do conhecimento, que podem ser classificados como técnicos, práticos e emancipatórios. Para o autor, o indivíduo é constituídos por três tipos de ações: ação teleológica (relaciona-se ao mundo objetivo - o agente planeja sua ação a fim de alcançar um objetivo); ação regulada normas (relaciona-se ao mundo social, ou seja, como as regras - os valores levam o agente a agir e implicam em suas interações); ação dramatúrgica (relaciona-se ao mundo subjetivo, ou seja, ao modo como o agente se vê em determinada situação). 
Essas três formas de ação são revistas por Van Manen, 1977 (apud LIBERALI, 1999), que propõe três tipos diferentes de reflexão:

1. Reflexão técnica: envolve o conhecimento técnico e formal, no sentido desse conhecimento ser utilizado com eficácia para alcançar determinados propósitos.

2. Reflexão prática: envolve a reflexão sobre o agir na ação.

3. Reflexão crítica: envolve tanto a reflexão técnica como a prática, mas ressaltando-se agora critérios de ordem moral, ou seja, há uma preocupação voltada para as implicações do agir profissional com termos como igualdade, justiça, democracia, etc.

Dessa forma, no processo de formação docente, o professor supervisor/orientador pode estimular o desenvolvimento reflexivo por meio de instrumentos, no nosso caso, consideramos o gênero textual como um instrumento propiciador da reflexão do professor em formação (ou em exercício).

\section{O papel do diário íntimo/compartilhado}

Os professores da Universidade Estadual de Maringá em formação produziram, ao longo do ano letivo de 2006, diários íntimos/ compartilhados. O objetivo era obter uma interação mais efetiva entre professor formador e professor em formação, tendo em vista, principalmente, o baixo índice de motivação e de confiança em si mesmos com que chegam a essa disciplina.

A noção de gênero como instrumento, proposta por Scheneuwly (2004), abriu-nos a possibilidade de, na disciplina de Prática de Ensino, no ano de 2006, utilizarmos o gênero diário, além do gênero diário de leitura e diário de aprendizagem.

Em relação especificamente ao diário íntimo, a opção por esse gênero se deu, em primeira instância, pelo fato de ele não apresentar um destinatário específico. Não queríamos que os professorandos es- 
crevessem para nós, professoras supervisoras, mas que vivenciassem uma escrita mais natural, sem preocupações avaliativas. Além dessa característica, outros papéis destacados por Machado (1998) a respeito do gênero diário são: - estabelecimento de contrato de confiança entre produtor e possível destinatário para a compreensão responsiva desse destinatário; - atribuição de franqueza pelo locutor, ao discurso produzido; - presença de referentes afetivos e cognitivos; -construção de um mundo discursivo conjunto ao da situação de comunicação; - ausência de preocupação com procedimentos de textualidade, como coesão e coerência,- criação de espaço para a constituição de subjetividades.

Considerando a atividade de escrita do diário como uma ação de linguagem (BRONCKART, 2003), o contex to de produção do diário íntimo foi, assim formado inicialmente:

- Lugar de produção = casa do professorando.

- Momento da produção = à escolha do professorando.

- $O$ emissor $=$ cada um dos professorandos (no total 24 alunos de Prática de Ensino).

- Receptor $=$ não havia, tendo em vista que uma das marcas do diário íntimo é a ausência do receptor.

- Lugar social da interação = universidade.

- A posição social do emissor (enunciador) = aluno de Prática de Ensino e professorando.

- Posição social do receptor $=$ não havia sido prevista, em um primeiro momento, tendo em vista o próprio gênero.

- Objetivo da interação = criar um espaço para a externalização de emoções e sensações durante a vivência da disciplina de Prática de Ensino.

Essas condições foram explicadas e definidas por mim e mais uma professora supervisora no início do ano letivo, sendo solicitado que os professorandos escrevessem esses diários, quantos quisessem, por ocasião de três momentos do estágio de docência: antes do estágio; durante a vivência do estágio e após o estágio.

É necessário esclarecermos que pedimos que escrevessem em um caderno pequeno próprio, mas não solicitamos a entrega. Não queríamos que eles vissem o instrumento como avaliação e nem que ti- 
vessem a nós, supervisoras, como interlocutoras. No entanto, aos poucos, os professorandos sentiram a necessidade de nos entregar o caderno, pedindo para que lêssemos os diários. Reforçava-se, assim, o que Bronckart (2003) afirma sobre o papel da avaliação na constituição do sujeito. Dessa forma, o diário íntimo começou a ser compartilhado com as professoras supervisoras, o que fez com que esse gênero - diário íntimo - começasse a se transformar, pela situação de circulação, no gênero diário compartilhado, agora tendo a nós, professoras supervisoras, como interlocutoras reais.

Da mesma forma, como professoras orientadoras também começamos a escrever nossos diários, expondo aos nossos alunos nossas sensações e angústias, com eles. Esse fato foi fundamental para otimizar a interação entre professoras formadores e professores em formação, já que vivenciávamos, nesse momento, a compreensão responsiva ativa bakthiniana.

A fim de evidenciarmos o papel assumido por esse gênero, organizaremos a análise em função dos momentos vivenciados pelos professores em formação.

\section{O momento anterior ao estágio}

Esse momento compreendeu várias atividades, bem como a utilização de diversos gêneros textuais, tais como: leitura dos textos embasadores do projeto de regência e elaboração de diários de leitura; - observação de aulas no ensino fundamental/médio e elaboração de diário reflexivo; - elaboração do gênero plano de aula; - apresentação do gênero microensino (no qual o professor em formação escolhe uma das aulas a ser ministradas em sua regência e apresenta-a para a sala, para posterior avaliação coletiva); elaboração da seqüência didática (doravante SD) a ser desenvolvida no estágio de docência.

Durante esse momento, os professores em formação, ao usarem o diário íntimo/compartilhado, trouxeram a tona várias funções assumidas pelo gênero e especificadas no quadro abaixo. Escolhemos as funções pelo número de ocorrências nos diários, sendo a função 1 a de maior representatividade, a 2 de menor e assim sucessivamente. 


\begin{tabular}{|c|c|}
\hline $\begin{array}{c}\text { PAPEL DO GÊNERO DIÁRIO } \\
\text { /COMPARTILHADO }\end{array}$ & EXCERTO \\
\hline $\begin{array}{l}\text { 1. Evidenciar o medo diante da vivência do } \\
\text { estágio. }\end{array}$ & $\begin{array}{l}\text { Meu Deus. Estou no último ano e agora estou } \\
\text { tomada por uma sensação de medo } \\
\text { absoluto.Cheguei na disciplina mais temida e } \\
\text { estou apavorada. Como dar aulas? O que } \\
\text { fazer? Não sei se terei coragem de enfrentar } \\
\text { uma sala de aula. }\end{array}$ \\
\hline $\begin{array}{l}\text { 2. Demonstrar a decepção com a realidade } \\
\text { observada nas escolas. }\end{array}$ & $\begin{array}{l}\text { As aulas que assisti foram horriveis. As } \\
\text { professoras não conseguem dominar os } \\
\text { alunos, os alunos não respeitam a professora. } \\
\text { O que mais me impressionou é que a gente } \\
\text { está falando tanto sobre planejamento e o que } \\
\text { a gente vê não é nada disso, a aula parece } \\
\text { não ter sido planejada, parece um 'faz de } \\
\text { conta', deprimente cena. }\end{array}$ \\
\hline $\begin{array}{l}\text { 3.Demonstrar a frustração da não vivência de } \\
\text { experiências de transposição didática. }\end{array}$ & $\begin{array}{l}\text { Precisamos montar exercícios de leitura e } \\
\text { análise lingüistica sobre o gênero } \\
\text { reportagem. As professoras fizeram um } \\
\text { microensino para nos ajudar. Mas não } \\
\text { adiantou, eu até sei as concepçóes de leitura, } \\
\text { mas quando tento fazer um exercício não saio } \\
\text { da decodificação ou vou muito além, já na } \\
\text { extrapolação. Não consigo entender essa } \\
\text { coisa de análise lingüistica, a professora } \\
\text { falou sobre a importância dos verbos discendi } \\
\text { na reportagem, mas como faço exercicios } \\
\text { desse tipo se nunca antes fizemos isso? }\end{array}$ \\
\hline $\begin{array}{l}\text { 1. Refletir sobre o desencontro teoria } \mathrm{x} \\
\text { prática. }\end{array}$ & $\begin{array}{l}\text { Fiquei pensando muito após ter feito o meu } \\
\text { estágio de observação. Porque a teoria é uma } \\
\text { e a prática é outra. Não pode ser só salário, } \\
\text { não creio que a qualidade do profissional } \\
\text { esteja motivada apenas em cima disso. Há um } \\
\text { desinteresse geral de alunos e de professores. } \\
\text { Para mim a questão é mais ampla, decorrente } \\
\text { de um mundo neo-liberal que corrói as } \\
\text { relações, que fragiliza as familias e que } \\
\text { debilita o professor. }\end{array}$ \\
\hline $\begin{array}{l}\text { 5.Refletir sobre a importância da interação } \\
\text { professor formador/professor em formação, } \\
\text { bem como vivenciar uma escrita em que se } \\
\text { tenha uma motivação para dizer. }\end{array}$ & $\begin{array}{l}\text { Professoras, amei o diário que cada uma fez... } \\
\text { sabe não botava fé nessa coisa de diário, mas } \\
\text { quando vocês também começaram a escrever } \\
\text { foi o máximo. Agora sou eu que escrevo, } \\
\text { escrevo... A gente foi se conhecendo melhor, } \\
\text { foi vendo que vocês também têm fragilidades. } \\
\text { Como a gente, fomos vendo as pessoas que } \\
\text { vocês são. Isso está sendo fundamental para } \\
\text { nós e nos está ajudando a termos mais } \\
\text { confiança. }\end{array}$ \\
\hline $\begin{array}{l}\text { 6.Evidenciar a dificuldade de relacionamento } \\
\text { dos pares de regência }\end{array}$ & $\begin{array}{l}\text { Meu companheiro de regência é uma figura } \\
\text { desafiadora, pois se tratava de um colega que } \\
\text { não aceitava opiniões, julgava que ninguém }\end{array}$ \\
\hline
\end{tabular}




\begin{tabular}{|l|l|}
\hline \multicolumn{1}{|c|}{$\begin{array}{c}\text { PAPEL DO GÊNERO DIÁRIO } \\
\text { /COMPARTILHADO }\end{array}$} & \multicolumn{1}{|c|}{ EXCERTO } \\
\hline $\begin{array}{l}\text { 7.Refletir sobre a dificuldade de } \\
\text { elaboração da SD }\end{array}$ & $\begin{array}{l}\text { Como é difícil fazer essa tal de seqüência } \\
\text { didática, só me dá branco.Já refiz a a } \\
\text { segunda aula três vezes e as professoras } \\
\text { me pediram agora que refizesse a quarta,. } \\
\text { Me sinto tão desorientada, tão perdida. } \\
\text { Acho que a palavra certa é desarmada. } \\
\text { Não imaginei que fosse tão difícil montar } \\
\text { um material didático, falta teoria, falta } \\
\text { base. Não sei se o exercício tá muito bobo } \\
\text { ou tá demais, não sei a dose certa. Estou } \\
\text { a beira de um colapso nervoso... }\end{array}$ \\
\hline 8. Refletir sobre a questão do tempo & $\begin{array}{l}\text { O que me afligi é o tempo, temos que } \\
\text { entender o gênero reportagem, temos que } \\
\text { observar aulas, preparar aulas, preparar } \\
\text { material, meu Deus tudo em um semestre. } \\
\text { Queria ter mais tempo para a prática. }\end{array}$ \\
\hline
\end{tabular}

Quadro 1. Papéis assumidos pelo gênero diário compartilhado antes da regência.

Percebe-se, em relação a esse momento, por meio da escrita dos diários, que o professor em formação deve levar em conta não apenas um diagnóstico teórico de seus professorandos mas, também, emocional. O medo diante do enfrentamento do estágio, além da dificuldade de lidar com os pares de regência ${ }^{2}$, foram revelados em quase todos os diários, o que comprova a necessidade de ser esse um aspecto a ser levado em discussão na sala de aula. Será por meio da discussão, da mediação entre formador e professorando que esses medos poderão ser ressignificados e potencializados em ações realmente significativas.

O desencanto também é frequente em relação ao estágio de observação. Para a grande maioria dos professorandos o medo inicial é seguido de uma sensação de impotência, de frustração, de perceber que a teoria aprendida no curso efetivamente não é transposta na sala de aula. E por mais lacunas teóricas que os professorandos apresentem, eles percebem esse desencontro. Mais uma vez, pensando na formação reflexiva desse profissional, utilizamos do genro sessão reflexiva para contrapor as aulas observadas às teorias apreendidas.

Em relação á escritura dos diários, percebemos que os professorandos ficaram motivados, na medida em que tinham o que dizer e buscaram um interlocutor para isso. Além disso, partiram de necessidades reais de interlocução, o que, sem dúvida, contribuiu para que esse gênero 
tornasse uma escrita significativa para grande parte da turma. Na verdade, quando os diários íntimos começaram a ser compartilhados criávamos um espaço discursivo propício à reflexão e ao alinhamento de novas ações em sala de aula, tanto nossas, supervisoras, como dos professorandos. Por isso mesmo, o gênero diário configurava-se, nesse momento, como um gênero catalisador (cf. SIGNORINI, 2006, p.8), isto é, como gêneros que "favoreceram o desencadeamento e a potencialização de ações e atitudes consideradas mais produtivas para o processo de formação".

Chama-nos atenção, também, a questão do tempo. Conforme Vygotsky (1988), o processo de internalização não ocorre de forma rápida. Assim, é natural que quando os alunos fossem expostos a um novo gênero, a sequiência didática, muitos apresentassem dificuldade em realizá-la e, alguns, como ocorreu depois, nem conseguissem fazêla corretamente. No entanto, o conflito é um estágio absolutamente necessário para desenvolvermos nossas capacidades reflexivas ou, valendo-nos de Vygotsky (idem), os chamados Processos Psicológicos Superiores, entre os quais está a própria escrita. De qualquer forma, por meio dos diários, podíamos compreender como ocorria esse processo no professorando, tanto no âmbito psicológico, como cognitivo.

\section{O momento do estágio}

No período do estágio (agosto, setembro e outubro) os professorando, além de vivenciarem a experiência de sua regência, também se colocam como observadores da regência do colega. Essa troca de vivência foi uma sugestão dos próprios alunos, de anos anteriores, que afirmavam ser muito mais interessante observar experiências planejadas pelos colegas.

Além dessa etapa, um gênero que acompanha esse momento é o gênero sessão reflexiva, que visa oportunizar aos professorandos o (re)olhar de sua prática, no sentido de auxiliá-los a analisarem a relação entre seus objetivos e suas práticas para, se necessário, reconfigurarem aquilo que eventualmente não deu certo/poderia ter sido melhor. Como professoras supervisoras nosso objetivo com a adoção desse gênero é auxiliá-los no processo de reflexão crítica, na compreensão de suas ações e na necessidade ou não de ressignificá-las. Assim, durantes esses três meses, agendamos vários encontros para essas sessões. Nesse mo- 
mento, a reflexão é estimulada tanto pelas professoras orientadores, por meio de questões e comentários, como também pelos colegas.

Em relação às funções que se desencadearam no diário íntimo/ diário compartilhado, no período do estágio de docência, tivemos:

\begin{tabular}{|c|c|}
\hline $\begin{array}{l}\text { PAPEL DO GÊNERO DIÁRIO } \\
\text { ÍNTIMO/COMPARTILHADO }\end{array}$ & EXCERTO \\
\hline $\begin{array}{l}\text { 1. Demonstrar a ansiedade em relação ao } \\
\text { início da regência. }\end{array}$ & $\begin{array}{l}\text { Já há dois dias não durmo direito. Será } \\
\text { que vai dar tudo certo? Será que os } \\
\text { alunos irão gostar de nossas aulas? Tive } \\
\text { uma crise de choro hoje, me senti incapaz, } \\
\text { impotente mesmo. Deixei tudo de lado, } \\
\text { familia, namorado, já decorei o material } \\
\text { de tanto lê-lo e relê-lo. Preciso me } \\
\text { acalmar. }\end{array}$ \\
\hline $\begin{array}{l}\text { 2. Refletir sobre problemas decorrentes de } \\
\text { "falta" ou "mal" planejamento, bem como } \\
\text { sobre a sensação de poder ter feito mais. }\end{array}$ & $\begin{array}{l}\text { As primeiras aulas foram ótimas. A } \\
\text { dinâmica da bata-quente com os temas } \\
\text { polêmicos funcionou bem. A professora } \\
\text { elogiou nossa atuação. Mas já na } \\
\text { terceira, quis morrer. Realmente não } \\
\text { tínhamos estudado muito a questão da } \\
\text { hipótese no texto dissertativo. Nem } \\
\text { articulamos isso com a tese. Daí um aluno } \\
\text { perguntou se a hipótese se transformaria } \\
\text { depois em tese. Eu disse categoricamente } \\
\text { que não e ainda reiterei a hipótese não } \\
\text { tem nada a ver com a tese é só uma } \\
\text { pergunta. No final da aula só de olhar } \\
\text { para a professora já sabia... seu olhar } \\
\text { direto já anunciava a minha bobeira. O } \\
\text { pior de tudo não foi isso, foram os alunos } \\
\text { dizendo que a aula havia sido ótima. } \\
\text { Otima? Eu insistindo em conteúdo } \\
\text { errado? Hoje entendi que ser professora é } \\
\text { mais do que fazer qualquer coisa. Eles } \\
\text { mereciam que a gente tivesse planejado } \\
\text { mais, estudado mais. Vou tentar consertar } \\
\text { o erro e ver como as coisas ficam. Só } \\
\text { sinto vontade de chorar e de me enfiar } \\
\text { num grande buraco. }\end{array}$ \\
\hline $\begin{array}{l}\text { 3. Alívio e surpresa diante do sucesso da } \\
\text { aula. }\end{array}$ & $\begin{array}{l}\text { A sala da quinta séria não parecia a } \\
\text { mesma. Na observação uns capetas e hoje } \\
\text { pareciam anjos (sem exagero).Uma linda } \\
\text { surpresa. Tudo saiu muito bem, o } \\
\text { planejamento deu certo. Organizamos a } \\
\text { sala, fomos conversando com eles, } \\
\text { distribuimos o material e eles } \\
\text { respondiam. Essa sensação é } \\
\text { maravilhosa, não simplesmente por que } \\
\text { eles ficaram quietos, mas porque eles } \\
\text { participaram ativamente da aula. }\end{array}$ \\
\hline
\end{tabular}




\begin{tabular}{|c|c|}
\hline $\begin{array}{l}\text { PAPEL DO GÊNERO DIÁRIO } \\
\text { ÍNTIMO/COMPARTILHADO }\end{array}$ & EXCERTO \\
\hline $\begin{array}{l}\text { 4. Reflexão sobre a importância do } \\
\text { planejamento e do estudo do gênero. }\end{array}$ & $\begin{array}{l}\text { Incrível, não sabiamos praticamente nada } \\
\text { do gênero notícia. Achávamos que não } \\
\text { iríamos conseguir e agora, em plena } \\
\text { regência, temos percebido pelos } \\
\text { exercícios, pela produção inicial que } \\
\text { realmente valeu a pena todo esforço para } \\
\text { ler os artigos teóricos dados pelas } \\
\text { professoras, as noites mal dormidas para } \\
\text { fazer um bom material. Quando olhei o } \\
\text { rascunho das primeiras produçóes vi que } \\
\text { havíamos feito alguma coisa por eles, a } \\
\text { custa de muito planejamento e dedicação. }\end{array}$ \\
\hline $\begin{array}{l}\text { 5. Reflexão catártica sobre a sessão } \\
\text { reflexiva e sobre a regência. }\end{array}$ & $\begin{array}{l}\text { Ai... professora, a minha sessão foi pra lá } \\
\text { de emocionante. Jamais ninguém na } \\
\text { minha vida falou coisas tão bonitas, nem } \\
\text { minha mãe em } 21 \text { anos disse coisas tão } \\
\text { importantes como você disse. Tenho muito } \\
\text { que aprender, mas a sessão reflexiva de } \\
\text { hoje me deixou de alma limpa. As coisas } \\
\text { que ouvi, mesmo as criticas,foram } \\
\text { absolutamente fundamentais para mim. } \\
\text { Sei que poderia ter evitado o choro, os } \\
\text { soluços, mas foi maravilhosos ouvir tudo } \\
e \text { de você. A minha regência foi, sem } \\
\text { dúvida, uma experiência maravilhosa, } \\
\text { sofri é verdade, não dormi direito, mas } \\
\text { valeu a pena ver que com esforço e estudo } \\
\text { a gente faz alguma coisa por aquelas } \\
\text { crianças. }\end{array}$ \\
\hline $\begin{array}{l}\text { 6. Reflexão sobre a interação entre os } \\
\text { parceiros da regência. }\end{array}$ & $\begin{array}{l}\text { Em poucos dias de regência percebi que } \\
\text { caira por terra o homem arrogante com } \\
\text { quem iniciei a regência. Era inacreditável } \\
\text { como depois de tanta tensão ele estava lá, } \\
\text { um companheiro que em quase quatro } \\
\text { anos não havia tido a possibilidade de } \\
\text { conhecer. Ficou interessado, se dispôs a } \\
\text { fazer mil coisas para nosso grupo, até } \\
\text { ligava para saber o que havia acontecido. } \\
\text { Ainda pessoalmente acho que ele deve ter } \\
\text { sido abduzido e que trocaram o chip dele } \\
\text { nesse tempo em que ele ficou tão distante } \\
\text { de tudo...mas o importante é que agora } \\
\text { conheci uma pessoa que jamais havia } \\
\text { visto antes. }\end{array}$ \\
\hline
\end{tabular}

Quadro 2. Papéis assumidos pelo gênero diário compartilhado durante da regência. 
O que nos chama atenção nos diários nesse momento é, principalmente, o fato de os professorandos perceberem a "utilidade" de todo o professo anterior de preparo e planejamento. Para aqueles que efetivamente dedicaram-se às leituras, à reescritura dos planos de aulas e dos módulos da SD, há uma sensação nítida de alívio e de encantamento, no sentido de conseguirem ter feito algo, em pouco tempo, por seus alunos. Da mesma forma, para aqueles que por questões pessoas, de tempo ou outras não se dedicaram, não refizeram os planejamentos, quando confrontados com a sala de aula e, principalmente, com a receptividade de crianças carentes, sentem um profundo remorso de não terem feito mais.

\section{O momento após o estágio de docência}

Além de os professores em formação terem uma sessão reflexiva final, nesse momento há a produção do diário reflexivo final (utilizando o modelo de SMITH, 1992), que serve como última etapa da avaliação do professorando.

Em relação aos papéis encontrados nos diários, tivemos:

\begin{tabular}{|l|l|}
\hline \begin{tabular}{|l} 
PAPEL DO GÊNERO DIÁRIO \\
ÍNTIMO/COMPARTILHADO
\end{tabular} & \multicolumn{1}{|c|}{ EXCERTO } \\
\hline $\begin{array}{l}\text { 1. Agradecimento e afirmação do desejo "ser" professor. } \\
\text { de }\end{array}$ & $\begin{array}{l}\text { Confesso que iniciei o ano não me } \\
\text { imaginando professora, e nem colocando } \\
\text { fé alguma nessa disciplina, mas saio dele } \\
\text { com um desejo enorme de realmente ser } \\
\text { professora. A disciplina Prática de Ensino } \\
\text { fez com que me reencontrasse, apesar de } \\
\text { todos os conflitos que vivenciei nela.O } \\
\text { exemplo de vocês professoras foi sempre } \\
\text { no sentido de encorajar, de ajudar e isso } \\
\text { foi um carinho maravilhoso. Nesse } \\
\text { momento eu só posso agradecê-las, por } \\
\text { tudo, por me orgulhar de dizer que quero } \\
\text { sim ser uma professora, que quero sim } \\
\text { contribuir com alguma coisa.O professor } \\
\text { aprendi isso é um ser compromissado com } \\
\text { seu aluno (não um missionário, pelo amor } \\
\text { de Deus), com sua sala, com a própria } \\
\text { sociedade. Saio do curso agora com a a } \\
\text { certeza de ter feito a escolha certa. Muito } \\
\text { obrigada. }\end{array}$ \\
\hline
\end{tabular}




\begin{tabular}{|c|c|}
\hline $\begin{array}{l}\text { PAPEL DO GÊNERO DIÁRIO } \\
\text { ÍNTIMO/COMPARTILHADO }\end{array}$ & EXCERTO \\
\hline 2. Reflexão sobre "ser" professor. (a). & $\begin{array}{l}\text { A disciplina da Prática de Ensino, sem } \\
\text { demagogias, me ajudou muito a refletir } \\
\text { sobre diferentes etapas da profissão de } \\
\text { ser professor. Refleti sobre o desencontro } \\
\text { da teoria e da prática, nos estágios de } \\
\text { observação, na análise do material } \\
\text { didático. Depois quando fomos desafiadas } \\
\text { a estudar um gênero que nem sequer } \\
\text { conhecíamos vi, ao final, que é possível } \\
\text { que o professor seja reflexivo e } \\
\text { pesquisador, é uma questão de tentar sair } \\
\text { dos modelos estruturalistas a que fomos } \\
\text { acostumados. Os diários e as sessões } \\
\text { reflexivas, então pareciam catarses } \\
\text { continuas que nos ajudavam tanto a } \\
\text { extravasar diferentes emoções, como } \\
\text { também a nos distanciar um pouco dos } \\
\text { fatos e a vê-los com um olhar mais crítico. } \\
\text { As atividades de planejamento se } \\
\text { mostraram imprescindiveis a um bom } \\
\text { profissional. Mas o bom professor não se } \\
\text { forma apenas com conhecimento formal, } \\
\text { enciclopédico. É preciso saber interagir, } \\
\text { interagir com alunos, com colegas, com a } \\
\text { sociedade. E fazer uma boa transposição } \\
\text { didática, etapa dificil que precisa ser } \\
\text { levada em conta no nosso curso.Como } \\
\text { professores podemos ajudar nossos } \\
\text { alunos a realmente buscarem um espaço } \\
\text { dentro da sociedade. Sonho? Não, } \\
\text { possibilidade quase concreta, porque } \\
\text { quando confiamos e fazemos um bom } \\
\text { trabalho esse alcance vai além da sala de } \\
\text { aula. E foi, principalmente, a interação } \\
\text { proporcionada por vocês supervisoras, o } \\
\text { organização, as discussões sempre } \\
\text { colaborativas e a paixão com que vocês } \\
\text { inúmeras vezes demonstraram nas aulas } \\
\text { só me deram ingredientes para realmente } \\
\text { tentar ser um bom professor. Sei que a } \\
\text { tarefa não é fácil, que as exigência são } \\
\text { muitas, que as cabeças arcaicas tentarão } \\
\text { sempre trazer obstáculos, mas me } \\
\text { descobri nesse ano capaz de superar, }\end{array}$ \\
\hline
\end{tabular}




\begin{tabular}{|c|c|}
\hline $\begin{array}{l}\text { PAPEL DO GÊNERO DIÁRIO } \\
\text { ÍNTIMO/COMPARTILHADO }\end{array}$ & EXCERTO \\
\hline 2. Reflexão sobre "ser" professor. (b). & $\begin{array}{l}\text { Meu estágio terminou e confesso que } \\
\text { estou aliviado. Não quero ser professor e } \\
\text { disso tive certeza agora. No início entrei } \\
\text { no curso porque tinha que fazer um curso } \\
\text { toois estava pressionado no meu } \\
\text { trabalho. Fui levando até chegar na } \\
\text { prática. Via as aulas e a motivação de } \\
\text { vocês professoras. Mas nada daquilo me } \\
\text { atingia. Quando entrei na sala e vi } \\
\text { aqueles adolescentes fiquei desesperado. } \\
\text { Não sabia como agir e não tinha } \\
\text { motivação para isso por mais que me } \\
\text { esforçasse. Nas sessóes reflexivas vi } \\
\text { colegas até chorando de felicidade por } \\
\text { esse momento quando eu sentia alivio. } \\
\text { Mas posso dizer que se talvez tivesse tido } \\
\text { essa experiência antes talvez tivesse a } \\
\text { coragem de mudar o rumo da minha vida } \\
\text { e ter feito o curso que realmente eu } \\
\text { queria, direito.Bem acho que isso já valeu } \\
\text { essa tomada de consciência o estágio e } \\
\text { vocês professoras me ajudaram a ter. }\end{array}$ \\
\hline
\end{tabular}

A principal contribuição lida nos diários dos professorandos nesse momento é, sem dúvida, a reflexão sobre a própria formação. Há aqueles, como o exemplo 'a' que têm uma experiência catártica com o estágio, mas há também aqueles como no exemplo ‘b’ que mesmo não querendo ser professores reconhecem tanto a importância do curso de Letras em propiciar experiências de ensino no decorrer do curso, e não somente ao final, quanto a tomada de consciência que se revela nessa etapa. Em ambos os casos, o papel do formador foi fundamental para a reflexão em torno da própria profissão.

\section{Conclusões}

Iniciamos este artigo com o propósito de verificar o papel do diário íntimo/ compartilhado como instrumento de reflexão na formação inicial.

Os resultados evidenciaram que esse gênero foi fundamental, pois propiciou diferentes formas de reflexão: 
- a técnica, ao refletir sobre o desencontro teoria x prática e a dificuldade na elaboração da SD (momento antes da regência) ou, ainda, sobre a importância do estudo do gênero (momento durante a regência) e a reflexão sobre ser professor (após a regência);

- a prática, no momento em que os professorandos registram a frustração de não terem vivenciado momentos de transposição didática em anos anteriores e, depois, durante todo o momento de estágio quando falam, por exemplo, dos problemas da prática decorrentes da falta de um melhor planejamento das aulas;

- a crítica, no momento final da disciplina, quando refletem sobre o que significa "ser" professor, bem como sobre as representações antes e após a regência. Etapa em que, evidenciaram que o compromissso do professor é, primeiramente, consigo mesmo, em busca de uma série de atributos necessários (conhecimento técnico, conhecimento prático, conhecimento interacional) e que vão além da sala de aula, devendo atingir também seu entorno.

Também ficou demonstrado que a transformação do diário íntimo em compartilhado, estabelecendo-se, portanto, a interlocução efetiva entre professor formador e professorando, foi essencial para que os professorandos transformassem suas representações sobre ser professor. Ao ler o diário de nossos alunos em formação e, principalmente, ao dar-lhes uma resposta, seja pelas ações na disciplina ou pelos diários compartilhados que escrevemos ou pelos bilhetes escritos nos diários compartilhados, exercemos aquilo que Bakthin (1992) chama de compreensão dialógica e responsividade. Ou seja, a compreensão sempre depende do reflexo do outro, da alternância de sujeitos e da resposta que cada um dá ao outro.

Além disso, para nós, professoras supervisoras de estágio, esse gênero trouxe contribuições valiosas no sentido de:

- evidenciar as angústias, incertezas dos professorandos, o que mobilizou novas ações em nossas práticas em sala de aula;

- oferecer informações de como os professorandos aprendem e regulam suas tarefas;

- oportunizar o reconhecimento do aluno, mas também da pessoa que ali se faz presente (abordagem mais personalizada de educação); 
- auxiliar o processo de interação entre os próprios professorandos;

- recuperar uma escrita mais espontânea e natural;

- demonstrar reflexões de ordem técnica, prática e crítica;

- levar o professorando a uma autoavaliação e à tomada de consciência de suas ações e de suas implicações;

- registrar experiências significativas;

- servir para a criação de um ambiente de encorajamento e de suporte às ações em sala de aula;

- proporcionar a autoavaliação do trabalho das supervisoras;

- servir como um instrumento de compreensão responsiva ativa entre os interactantes, bem como de integração afetiva entre eles (o que pode auxiliar/otimizar o processo de ensino e de aprendizagem).

Apesar dessas conclusões não serem de todas "aplicáveis" a outros contextos, nem mesmo a todos os professorandos da turma, pois houve aqueles que não interagiram com o instrumento, nem tão pouco com esse momento da formação, cujos motivos não dizem respeito ao objetivo desse artigo no momento, ao menos podemos afirmar que a utilização do gênero diário íntimo/compartilhado mostra-se extremamente relevante em disciplinas que envolvam o agir do professor em formação. Instrumento produtivo tanto para professores em formação quanto para os próprios professores formadores. No entanto, como todo instrumento, sua utilização vincula-se, sobremaneira, às formas de mediação que serão efetivadas pelo professor formador.

Foi, sem dúvida, por meio desse gênero que os professorandos puderam não só refletir como sentir, informar, questionar, sempre respondendo algo. Foi também por meio dele que as professoras formadoras puderam se autoavaliar, conhecer melhor seus alunos, realinhar suas práticas metodológicas e, em decorrência disso, diagnosticar problemas e dificuldades que transcendem o já conhecido conhecimento técnico.

Por isso mesmo, a utilização desse gênero, em práticas de formação, além de colaborar para a compreensão do agir do professor em formação, retira a irresponsividade tão comum no meio acadêmico e, principalmente, reforça a própria natureza dialógica intrínseca ao texto escrito. 


\section{Notas}

1 O termo é utilizado tal como postula Bourdieu (1972:178-9), como: “(...) um conjunto de esquemas que permite engendrar uma infinidade de práticas adaptadas às situações sempre renovadas sem nunca se constituir em princípios explícitos ou ainda esse sistema de disposições duradouras e transponíveis que, integrando todas as experiências passadas, funciona, em cada momento, como uma matriz de percepções, de apreciações e de ações e torna possível a concretização de tarefas infinitamente diferenciadas, graças às transferências analógicas de esquemas que permitem resolver os problemas da mesma natureza".

2 No caso da turma em questão, o estágio de docência foi realizado em dupla.

\section{Referências}

BAKTHIN, Mikail. Estética da criação verbal. São Paulo: Martins Fontes, 1992.

BRONCKART, Jean-Paul. Atividade de linguagem, textos e discursos: por um interacionismo sócio-discursivo. Trad. Anna Raquel Machado e Péricles Cunha. São Paulo: EDUC, 2003.

GIMENES, Telma. (Org) Trajetória na formação de professores de línguas. Londrina: Ed. UEL, 2002.

HABERMAS, J. Consciência moral e agir comunicativo. Trad. Guido A. de Almeida. Rio de Janeiro: Tempo Brasileiro, 1989.

HILA, Cláudia Valéria Doná. Gêneros textuais e a formação dos professorandos no curso de Letras. In: Anais... I Congresso LatinoAmericano sobre formação de professores de línguas. Florianópolis: UFSC, nov., 2006, p. 112-129.

Esquemas de ação e habitus dos professorandos de Letras nos estágios supervisionados. Anais... XIV Semana de Letras, Universidade Estadual de Maringá, junho, 2004. p.54-65.

LIBERALI, Fernanda Coelho. O desenvolvimento reflexivo do professor. The Especialist. São Paulo, vol.17, n.1, 1997, p.19-37. 
O diário como ferramenta para a reflexão crítica. Tese (Doutorado). São Paulo: PUC, 1999.

MACHADO, Anna Raquel. O diário de leitura: a introdução de um novo instrumento na escola. $1^{\text {a }}$. ed. São Paulo: Martins Fontes, 1998.

MAGALHÃES, Maria Cecília Camargo. Projetos de formação contínua de educadores para uma prática crítica. The Especialist. São Paulo, vol.19, n.2, 1998, p169-184.

SCHNEUWLY, Bernard. Gêneros e tipos de discurso: considerações psicológicas e ontogenéticas. In: ROJO, Roxane.; CORDEIRO, Glaís S.(Orgs.) Gêneros orais e escritos na escola. Campinas, SP: Mercado de Letras, 2004.

SMITH, J. Teachers work and politics of reflection. American Educacional Research Journal, 29 (2),1992, p. 267-300.

VYGOTSKY, Lev Semyonovich. Internalização das funções psicológicas superiores. In: . A formação social da mente. São Paulo: Martins Fontes, 1978, p.59-65. 


\title{
The daily gender in the initial formation of the teacher
}

\begin{abstract}
As part of the research group "Interação e escrita no ensino $e$ aprendizagem" (Interaction and writing in teaching and learning - UEM/ $\mathrm{CNPq}$ ), this work aims to discuss the partial results on the role of the personal/ shared diary genre in the discipline Teaching Practice in Portuguese Language, from the perspective of the social interactionism and Bronckart's sociodiscursive interactionism. During the year 2006, student-teachers produced personal diaries whose ultimate aim was mainly to obtain a more effective interaction between the teacher developer and the teacher under development (the student-teacher), having in mind, mainly, the low rate of motivation and trust with which the academics start this discipline. However, besides this role, others related to this genre came up. This study points to the importance of seeing text genres as a psychological tool (cf. SCHNEUWLY, 1994), in the vygotskyan sense of the term, which means that the diary can be considered an interesting instrument for the initial stage of teachers' development.
\end{abstract}

Keywords: diary; interaction; writing.

Recebido em jan. de 2008

Aceito em maio de 2008 